\title{
Disposal of technological sludge of railway infrastructure enterprises
}

\author{
Yuliia Zelenko ${ }^{1}$, Maryna Bezovska ${ }^{1}$, Anna Leshchynska ${ }^{1}$, and Alexandr Shnaiderman ${ }^{1}$ \\ ${ }^{1}$ Dnipro national university of railway transport named after academician v. Lazaryan, 49010 Dnipro, Ukraine
}

\begin{abstract}
The problem of improving environmental safety in the handling of oily waste and sludge is relevant for most industries. Significant amounts of waste oil adversely affect virtually all components of the environment. However, it is also a valuable hydrocarbon feedstock. Thus, a rational approach to the processing of sludge can have a significant environmental and economic effect. The shortcomings of traditional thermal technologies for the disposal of technological sludge and suggests using much cheaper mechanical methods were discussed in this article. For example, install decanters of various designs in a depot depending on the overall composition of the sludge and the composition of each of its main parts: the carbon-containing part, water and mechanical impurities. A modern scheme for the disposal of technological sludge from railway infrastructure enterprises has been proposed. Such a scheme allows to reduce the man-made load associated with their accumulation, circulation and minimization. The most promising example of the use of the proposed technology of utilization of oil sludge is its implementation at the local sewage treatment plants of locomotive and wagon depots.
\end{abstract}

\section{Introduction}

Process sludge (oil sludge) of the treatment facilities is visually thick, viscous pasty mass with separate inclusions of mechanical impurities, clusters of heavy oils and grease oils. Sludge is watered enough (water content from 20 to $70 \%$ ). In most cases, it contains an average of $30 \%$ or more of petroleum products and has the combustion heat of $3000-5000 \mathrm{kcal} / \mathrm{kg}$.

\section{Materials and Methods}

The chemical composition of the sludge is very complicated. In addition, not all of their fractions can be burned or recycled. The oil sludges are diverse in composition; they contain oil, water, oil emulsions, asphaltenes, tars, heavy metal ions, various mechanical impurities and radioactive elements. When stored for a long time, they separate into layers: the upper layer is an emulsion of oil with water, the middle layer is clarified water with petroleum products, the lower layer - solid phase $(70 \%)$, impregnated with petroleum products. The lower layer (bottom sediment) contains $26-45 \%$ of resinasphalt substances and $15-30 \%$ of paraffins, as well as combined oil, clay, sand, water, corrosion products.

Disposal of process sludge is somewhat complicated due to the significant difference in the composition and properties of the three fractions of process sludge, namely oil, water and solid. Disposal of oil sludge is possible in several ways:

- Mechanical;

- Physico-mechanical;
- Thermal;

- Using bio- and chemical technologies [1-4].

In accordance with the decisions made, spent petroleum products are subject to mandatory collection and disposal, and in some cases to destruction [5].

The most effective way of disposal is regeneration the recycling of waste oils in order to completely restore their primary properties, which is usually carried out through complex multi-stage processing at specialized plants.

The constant emergence of new ways and means for solving the disposal problems, the creation of more advanced, waste-free methods of regeneration of waste lubricants, the issues of ecology and human health cause the need for constant attention to this problem, which is at the intersection of technology, ecology and economy.

The oil sludge of linear divisions of railways accumulates in the waste water of enterprises after the washing of cars, locomotives and their parts; therefore, the largest number thereof is formed in the railway passenger train and car-repair sheds, as it is here where the rolling stock is washed while being repaired.

For example, the sludge can be formed during the large periodic maintenance of rolling stock TP-2, which is carried out in special shops of the repair and maintenance depots. This type of repair presupposes body lifting, bogie rolling out, disassembling of individual units, removing of covers and caps, painting of diesel locomotives, painting of electric locomotives, as well as workpiece washing.

The oil sludge is also formed during the hoist repair of TP-3. It includes the removal of traction engines, 
rolling out of wheelsets, dismantling and disassembly of units for reliable inspection and repair, painting of interior and exterior surfaces with the previous mandatory washing [5-8].

For example, sludge formation is an accompanying process of the work done by the bogie, wheel, gearbox sections of the depot that carries out washing of cars, boxes, wheel sets, reduction gears.

The enterprises of different services annually produce between 6 and 9 tons of process sludge. If you look at the percentage ratio, you can see that a significant part (almost 40\%) is occupied by them within the total amount of the passenger service waste.

Outside, industrial waste of process sludge is a mass of brown colour, which has a lump structure. More often, the process sludge falls into the third hazard class and is moderately hazardous.

Table 1 shows the results of chemical analysis of process sludge of the Dnipro passenger train depot.

Table 1. Analysis of process sludge

\begin{tabular}{|c|c|c|c|c|c|}
\hline \multirow{2}{*}{$\begin{array}{c}\text { Metal content, } \mathrm{mg} / \mathrm{kg} \\
\text { hazard class }\end{array}$} & \multicolumn{5}{|c|}{ Form of presence } \\
\hline & Total & Active & Water-soluble & Solubility, g/100 g & Content in waste, $\mathrm{kg} / \mathrm{t}$ \\
\hline $\mathrm{Pb}(1)$ & 37 & 0 & 0 & 0 & 0.037 \\
\hline $\mathrm{Cd}(1)$ & \multicolumn{5}{|c|}{ absent } \\
\hline $\mathrm{Zn}(2)$ & 23.8 & 6.2 & 0.4 & 13 & 0.023 \\
\hline $\mathrm{Ni}(2)$ & 13 & 3.5 & 1.3 & 1.2 & 0.013 \\
\hline $\mathrm{Cu}(2)$ & 5 & 2 & 0.5 & 1 & 0.005 \\
\hline $\operatorname{Cr}(2)$ & 10 & 0 & 0 & 0 & 0.01 \\
\hline Co (2) & \multicolumn{5}{|c|}{ absent } \\
\hline $\operatorname{Mn}(3)$ & 8.8 & 3.5 & 0 & 0 & 0.008 \\
\hline Oils and etroleum products & 528046 & - & - & 0.002 & 500 \\
\hline
\end{tabular}

During the researches for determination of heavy metals, the applied method is atomic absorption spectroscopy; for determination of petroleum products chromatography. According to the analysis results, the sludge was classified as third-class toxicity, i.e. moderately hazardous $[9,10]$.

Today, process sludge is accumulated at railway enterprises and subsequently transferred under contracts to other organizations for disposal. The widely-used are physico-mechanical and thermal methods, which is explained by the specific composition of such sludge; various bio- and chemical technologies are also known.

The simplest methods are disposal of oil-containing waste at specialized landfills. But such methods do not solve the main problems and can only be used as auxiliary preliminary measures.

Among other physical and mechanical methods, the most technological, economic and simple method of recycling process sludge with a maximum moisture content up to $80 \%$ is a method of cube fractionation, which is a gradual evaporation, when the generated steam is carried-off continuously as it is released; only a liquid phase remains in the system and it is in equilibrium with the steam.

The process of gradual evaporation is usually carried out in cubic devices of periodic action. Often, the main product of distillation is fraction with the boiling temperature corresponding to that of paraffins. This method is quite energy-consuming, but the resulting product has a high price. The disadvantage of this method can be called the danger of creating and working with vacuum, which "accelerates" the fractionation.

One of the most common ways of oil sludge disposal is such thermal method as incineration. However, process sludges are limited combustible substances, so their incineration can be carried out only with the use of additional fuel. For example, for railway transport enterprises, it is proposed to burn them when mixed with solid fuels in furnaces of stationary locomotives located on the territory of the depot. It is recommended to check the ash remaining after incineration for the presence of heavy metals.

However, such technologies are low-efficiency, energy and financially expensive due to the high cost of boiler units, in addition, it is necessary to install additional expensive equipment for the purification of emissions into the air; they do not allow the full processing and disposal of oil sludge and do not provide environmental safety.

Biological methods are based on scientific developments in the field of accelerating natural processes of self-healing and self-purification of soils and reservoirs, that is, these methods are adapted for use on natural objects: earth mud, in case of oil spills on soil and water systems.

Chemical methods are based on the use of reagents that cause the oxidative decomposition of petroleum hydrocarbons. Chemical substances and decomposition products (carcinogenic and mutagenic substances benzo $(\alpha)$ pyrene, phenols, polycyclic hydrocarbons and other hazardous compounds) are generally even more dangerous than primary petroleum contamination. Nevertheless, they found their application.

When selecting the process sludge disposal technology, it is necessary to take into account the frequency of generation of these wastes, their limited quantity, the considerable consumption of additional fuel that will support the incineration process. That is why, in order to take into account these features of the sludge of railway companies, we propose to use considerably cheaper mechanical methods. For example, to equip the depot with decanters of various designs depending on the general composition of the sludge and the composition 
of each of its main parts: hydrocarbon-containing part, water and mechanical impurities.

The decanter is a centrifuge with a digital conveyor. The rotor consists of conical and cylindrical drum parts, a screw conveyor and a feed mechanism pipe. Such a unit separates polluted oil, as well as oil sludge of various origins, into the hydrocarbon phase with a separation of water and solids [4].

The process is conducted due to the separation of the mixture into three phases based on the difference in their density using various ranges of high velocities and torques. from the remote control unit. Also, manufacturers note that in case of unauthorized shutdown of the The raw material (contaminated petroleum products) is fed through the feed mechanism pipe to the rotating part of the screw conveyor, where, under the action of centrifugal force, it is separated into the clarified product and the precipitate.

The clarified product is removed from the cylindrical part of the rotor, and the precipitate due to the difference in speeds of the screw and rotor enters the conical part, where it is dewatered. The dehydrated precipitate is unloaded at the narrow end of the conical part through special ports. The decanter is controlled fan the burning is maintained by natural draft.

Such installations provide the incineration of petroleum products in standard containers, the ability to dispose of waste directly at the place of their formation on a specially designated area of any depot. Separately we should note the higher quality of incineration compared with open burning, high level of explosion safety due to intensive blowing of the combustion chamber.

Since the oil sludges of the railway enterprises are sufficiently flooded, as they are the rolling stock washing waste, they do not need to be further diluted with water to reduce the percentage of mechanical impurities. It is recommended to use the decanters with a screw, which has a coating with special protection, for example, from ceramics or tungsten carbide.

Such measures are due to the presence in the process sludge of so-called "hard" mechanical impurities (sand, scales, metal shavings, etc.), which can cause the early wear of the working parts of equipment. Additionally, in order to prevent the penetration of large mechanical impurities into the decanter, it is expedient to install the mesh filters of different fineness of purification or vibration separators.

The decanter efficiency depends on such indicators of raw material as its uniformity and temperature. The first indicator will allow the decanter to operate in a continuous mode and avoid permanent human control over its operation parameters; because the settings of the decanter to the required parameters take the employee who serves it minimum 15 minutes.

The second indicator provides the required viscosity of raw materials and usually is $80-90^{\circ} \mathrm{C}$; the higher temperature can lead to overheating of the unit. As a rule, such heating is carried out directly in the sludge storage facility (due to heating of the intermediate containers) or "on the go" with the help of special heat exchangers when the oil sludge gets heated while passing through them $[9,11]$.

We can use regular mesh filters as a coarse filter. To obtain a product with a higher percentage of clarification, it is suggested to use the intermittent filters, for example, filter presses $[4,12,13]$.

Filter presses have such advantages as significant filter surface, simple design, option to disconnect individual non-working plates.

Such a disadvantage as manual operation, which causes delays in the work, is not significant for the railway companies due to the small amounts of sludge generation. As a heat exchanger it is possible to offer, for example, shell-and-tube heat exchangers with U-tubes.

Practical studies have shown that for the optimal separation of the three phases of process sludge, different types of flocculants are needed for each case. Depending on the type of equipment used for processing oil sludge (centrifuges, filter presses, vacuum filters) the most suitable type of reagents is selected and used for further processing.

From the experience of using the cationic flocculants most effectively act on organic compounds, while anionic ones are more suitable for inorganic substances. Due to the diversity of sludge composition and properties, the selection of effective flocculants in each individual case should be carried out based on the preliminary laboratory and experimental-industrial tests.

\section{Results}

For example, there are widely known such flocculants as FT-410, PT-506, flocculants of Zetag-89 brand, technical polyacrylamide (PAA) and others. So the water-based cationic flocculant Zetag-89 manufactured by the Swiss company Ciba Specialty Chemicals is used in the oil refining industry in the sludge dehydration process in amount of $2 \mathrm{~kg}$ per ton of dry residue [14].

There are known research results of the sludge clarification in the presence of flocculants of the brands Zetag-89, Praestol 853 and polyacrylamide at a dosage of $10 \mathrm{~g}$ per ton of sludge. The obtained results showed that at low amounts of the flocculant it is possible to separate mechanical impurities from petroleum products rather accurately. The content of petroleum products in the lower precipitate layer using flocculants of the Zetag89 and Praetol 853 brands was 6-10\%, and in the precipitate without the use of flocculants - $18 \%[9,14$, 15].

As flocculant reagents, we tested surface-active substances (sulfonol, neonol AF 9-12, cocamidopropyl betaine) in conjunction with the classical reagent polyacrylamide (PAA), which is widely used for separating oil sludge, to accelerate the latter.

The test was as follows: the process sludge was heated to a temperature of $85^{\circ} \mathrm{C}$; PAA was added in the amount of $1 \%$ by weight and stirred for 5 minutes; surfactant was added in the same amount as polyacrylamide, stirred for 5 minutes; the mixture was centrifuged for 30 minutes at a rate of $3000 \mathrm{rpm}$; then we observed the mixture separation (Fig. 1-4). 


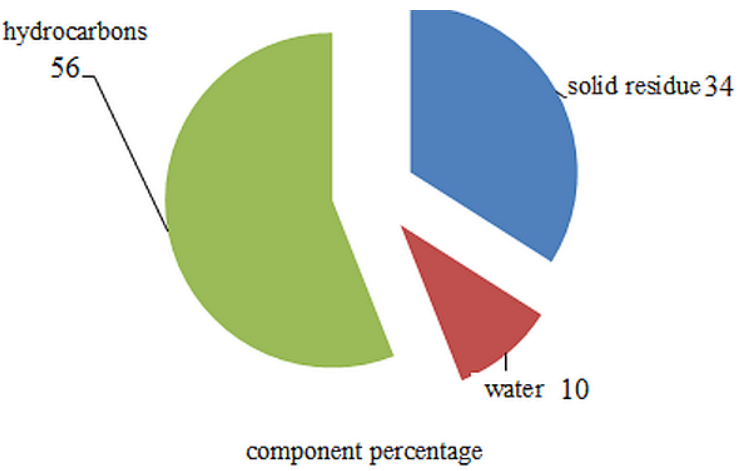

Fig. 1. Dependence of the degree of process sludge fractionation after the addition of polyacrylamide

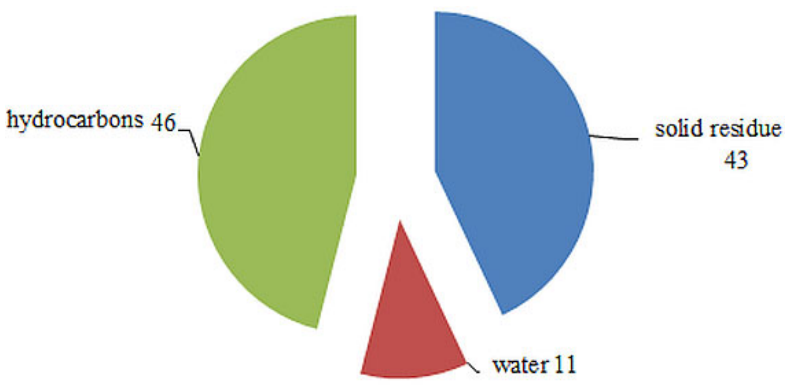

component percentage

Fig. 2. Dependence of the degree of process sludge fractionation after the addition of polyacrylamide and sulfonol

As can be seen from the figures, the best result, that is, the effective separation of the mixture into three fractions - solid residue, water, hydrocarbons, was obtained by combining polyacrylamide with sulfonol. Therefore, we propose the use of polyacrylamide flocculants in combination with sulfonol ("technical" paste) [4].

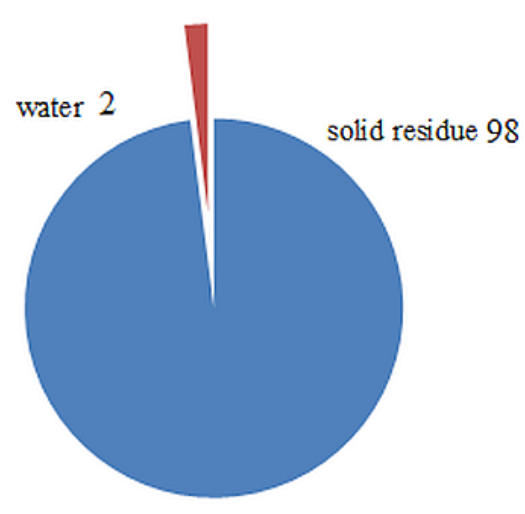

component percentage

Fig. 3. Dependence of the degree of process sludge fractionation after the addition of polyacrylamide and neonol AF 9-12

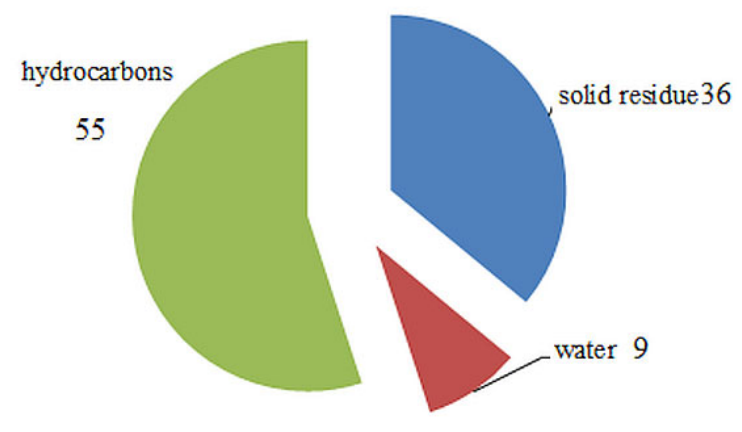

component percentage

Fig. 4. Dependence of the degree of process sludge fractionation after the addition of polyacrylamide and cocamidopropyl betaine

Also we obtained kinetic dependences of the degree of process sludge fractionation, shown in Fig. 5-7 (except for the case of combination of neonol with PAA due to the worst result obtained - Fig. 3).

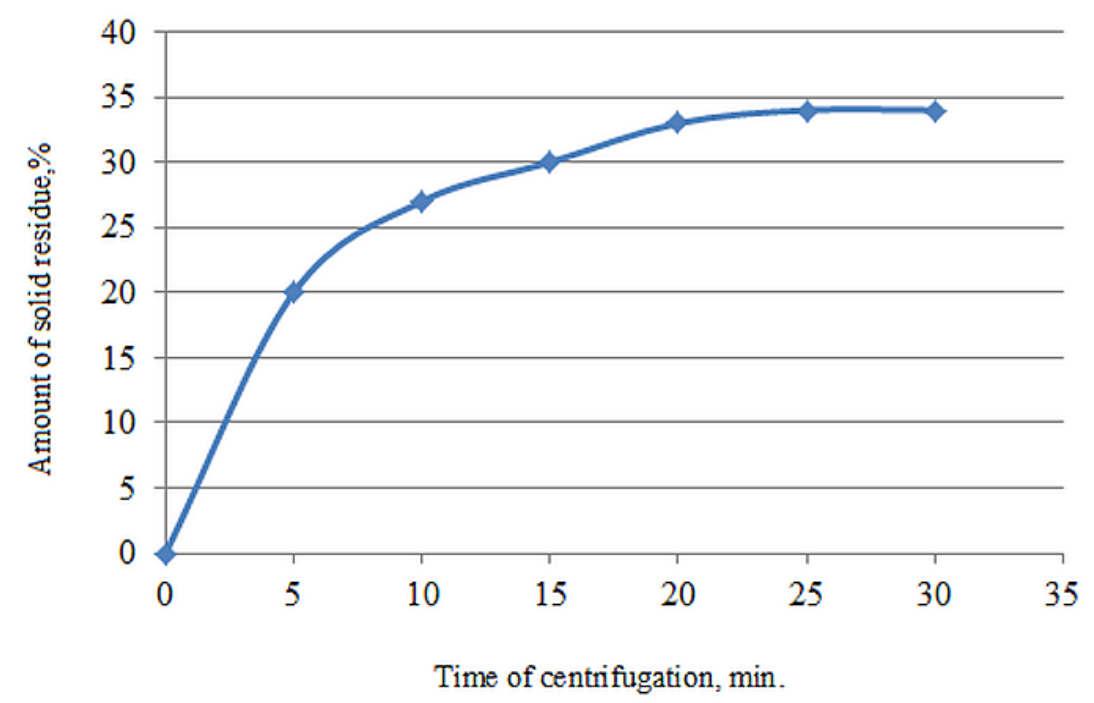

Fig. 5. Kinetic dependence of the degree of process sludge fractionation with the addition of polyacrylamide 


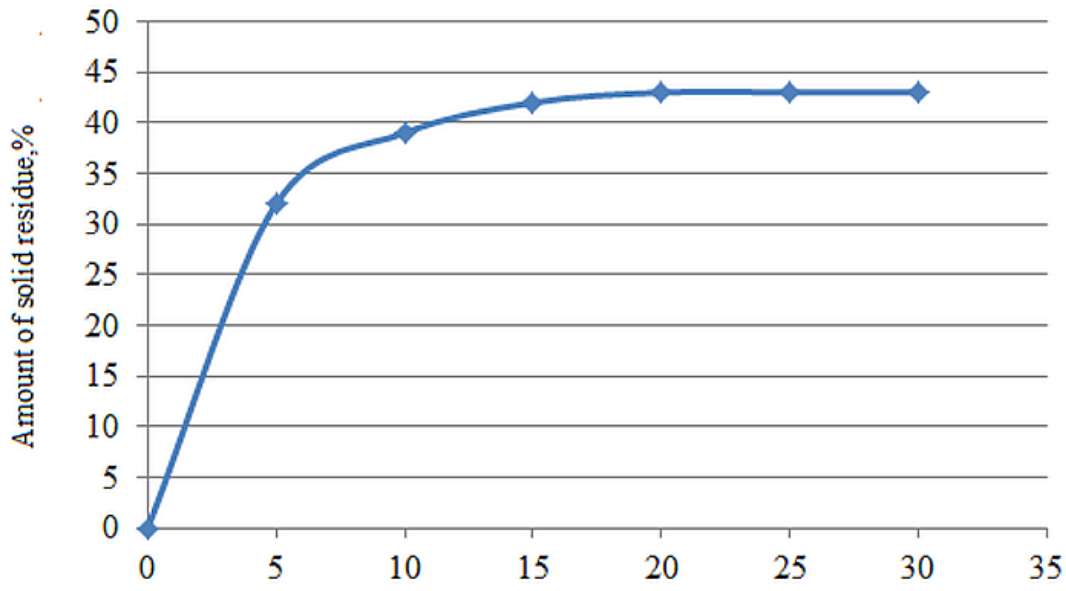

Time of centrifugation, $\mathrm{min}$.

Fig. 6. Kinetic dependence on the degree of process sludge fractionation with the addition of polyacrylamide and sulfanol

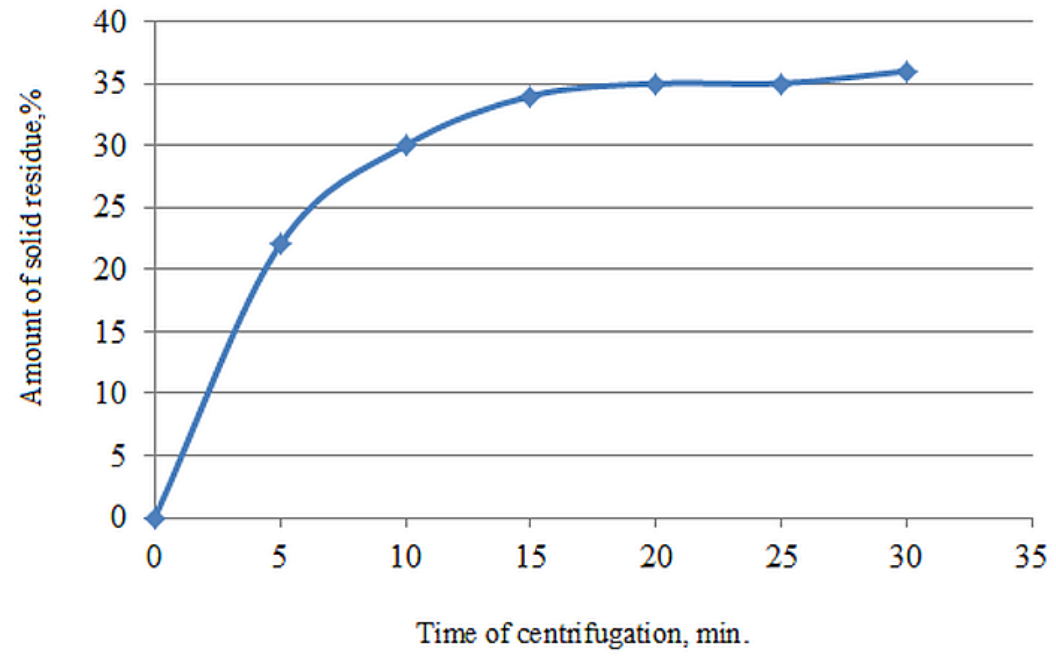

Fig. 7. Dependence of the degree of process sludge fractionation with the addition of polyacrylamide and cocamidopropyl betaine

\section{Discussion}

As can be seen from the figures, the amount of solid residue formed during the centrifugation process was selected as the tested parameter. Since in the case of PAA combination with sulfonol, the most qualitatively purified products (hydrocarbons and water) were obtained, as they contained the smallest amount of mineral and other impurities, we propose to use polyacrylamide flocculants in combination with sulfonol ("technical" paste).

The water remaining after sludge clarification is sent to the advanced treatment and can subsequently be used, as already mentioned above, for the preparation of a solution of reagents, as technical water in the process cycle of the enterprise or can be discharged into water bodies.

In order to remove the precipitate with a high content of mechanical impurities and heavy metals there are usually offered several options:
- $\quad$ Their disposal at the landfill;

- Incineration;

- Their gradual decomposition by means of biologically active sorbents at specially prepared sites.

In the conditions of depot it is possible to gradually accumulate such waste and dispose of them at the landfills.

\section{Conclusion}

Thus, in the course of work we investigated the industrial processes, resulting in process sludge waste. We analyzed their composition and properties and as a result it was found that they contain such dangerous components as heavy metals, which confirmed their rating as the third hazard class and the need for their detailed study.

We also proposed the principal scheme of reagent oil sludge processing with the use of the decanter and heat exchanger, which allows to obtain the purified products 
(hydrocarbons and water) that can be used in the technological processes of the enterprise; we carried out the experimental studies on the selection of flocculant reagents. The obtained kinetic dependences of the degree of process sludge fractionation confirmed the correctness of the choice of reagents and provided opportunities for optimization and prediction of the process of separation and clarification of oil sludge.

\section{References}

1. V.N. Plakhotnik, Ju.V. Onyshchenko, L.A. Yaryshkina L.A., The environmental impacts of railway transportation in the Ukraine, Transportation Research Part D: Transport and Environment, 10 (3), pp. 263-268 (2005).

2. Yu. V. Zelenko, Naukovi osnovy ekolohichnoi bezpeky tekhnolohii transportuvannia ta vykorystannia naftoproduktiv na zaliznychnomu transporti monografiia, Izdatelstvo Makovetskii, 242 p. (2010). [in Ukrainian]

3. Yu. V. Zelenko, M. S. Bezovska, A. L. Leschynska, Rozrobka innovatsiinych resursozberihayuchykh tekhnolohii utylizuvannia naftovmischuyuchykh vidkhodiv, Gurnal «Tekhnolohicheskii audit I rezervy proizvodstva», PP «Tekhnolohichnyi tsentr», p. 17-21, (9) (2013). [in Ukrainian]

4. M. S. Bezovska, Yu. V. Zelenko, Rozrobka suchasnykh pryntsypiv utylizatsii tekhnolohichnykh shlamiv pidpryyemstv zaliznychnoi infrastruktury, Zbirnyk naukovykh prats Donetskoho instytutu zaliznychnoho transportu Ukrainskoi derzhavnoi akademii zaliznychnoho transportu, Vudavnytstvo Donetskoho instytutu zaliznychnoho transportu, 27, p. 159-162 (2011). [in Ukrainian]

5. Rekomendacii z orhanizatsii resursozberihayuchykh zakhodiv na obyektakh lokomotyvnoho hospodarstva Ukrzaliznytsi. TST-0202, Ministerstvo transport ta zviazku Ukrainy, Polohrafservis, 85 p. (2011). [in Ukrainian]

6. M. M. Uzdin, V. I. Kovalev, Obschiy kurs zheleznykh doroh, Akademiya, 252 p. (2012). [in Russian]

7. L. F. Khaskin, V. N. Matveev, Ekonomika, orhanizatsiya $i$ upravleniye lokomotivnym khoziaistvom, Marshrut, 452 p. (2002). [in Russian]
8. S. Myamlin, L. Neduzha, Z.Urbutis, Research of Innovations of Diesel Locomotives and Bogies, Procedia Engineering, 134, pp. 469-474, (2016).

9. M. S. Bezovska, Yu. V. Zelenko, V. M. Plakhotnyk, L. O. Yaryshkina, Utylizatsiya naftovmisnykh tekhnolohichnykh shlamiv strukturnykh pidrozdiliv zaliznyts, Zbirka tez dopovidey II Mizhnarodnoi Konferentsii $\mathrm{z}$ pytan povodzhennya $\mathrm{z}$ vidkhodamy vyrobnytstva ta spozhyvannya, p. 21-22 (2007). [in Ukrainian]

10. Yu. V. Zelenko, L. D. Tarasova, M. S. Bezovska Pidvyschchennya rivnya ekolohichnoi bezpeky pry povodzhenni $z$ vidpratsovanymy motornymy olyvamy zaliznychnoi infrastruktury: monographiya, Vudavnytstvo «Litohraf», 150 p. (2016). [in Ukrainian]

11. Yu. V. Zelenko, S. V. Miamlin, Ekolohoekonomichni zakhody stabilizatsii ta polipshennya stanu dovkillya na zaliznytshnomu transporti, Zbirnyk naukovukh prats Dnipropetrovskoho natsionalnoho universytetu zaliznychnoho transport imeni akademika V. Lazariana «Problemy ekonomiky transportu», 7, p. 47-53 (2014). [in Ukrainian]

12. M. S. Bezovska, Yu. V. Zelenko, L. O. Yaryshkina, O. B. Babenko, Utylizatsiya naftoshlamiv ta mastyl, utvorenukh u strukturnykh pilrozdiliv zaliznyts, Naukovo-praktychnyi zhurnal «Zaliznytchnyi transport Ukrainy», DNDTS UZ, 1, p. 36-38 (2008). [in Ukrainian]

13. Zelenko Yu., Myamlin S., Sandovskiy M., Scientific foundation of management of the environmental safety of oil product turnover in railway transport, Litohraf, 332 p. (2014).

14. A. V. Hrechanikov, A. P. Platonov, S. H. Kovchur, A. S. Kovshur, Novyie koahulyanty i flokulianty $v$ protsessakh vodopodhotovki, Vestnik Vitebskoho hosudarstvennoho universiteta, 23 (2012). [in Russian]

15. Zelenko Yu. V., Miamlin C, V., Neduzha L. O., Parametrytshna ekolohiya na zaliznytshnomu transporti: pryntsypy, otsinka, kontrol, bezpeka: monohrafiya, Litohraf, 240 p. (2014). [in Ukrainian] 